\title{
The Effects of All-Trans Retinoic Acid on the Induction of Oral Tolerance in a Murine Model of Bronchial Asthma
}

\author{
Hirotaka Sakamoto ${ }^{a}$ Toshiyuki Koya $^{a}$ Keisuke Tsukioka ${ }^{a}$ Kenjiro Shima ${ }^{a}$ \\ Satoshi Watanabe ${ }^{a}$ Hiroshi Kagamu $^{\text {a }}$ Yosuke Kimura $^{a}$ Takuro Sakagami $^{\mathrm{a}}$ \\ Takashi Hasegawa $^{\text {b }}$ Eiichi Suzuki $^{\text {b Ichiei Narita }}{ }^{a}$ \\ ${ }^{a}$ Division of Respiratory Medicine, Department of Homeostatic Regulation and Development, Niigata University \\ Graduate School of Medical and Dental Sciences, and b Department of General Medicine, Niigata University Medical \\ and Dental Hospital, Niigata, Japan
}

\section{Key Words}

All-trans retinoic acid - Bronchial asthma $\cdot$ Oral tolerance .

Regulatory T cell

\section{Abstract}

Background: Active suppression induced by regulatory $T$ (Treg) cells is reported to be one of the mechanisms involved in oral tolerance. All-trans retinoic acid (ATRA) has been reported to affect Treg cell differentiation. The present study examined the effects of ATRA on the induction of oral tolerance in a murine model of bronchial asthma. Methods: $\mathrm{BALB} / \mathrm{c}$ mice were sensitized to and challenged with ovalbumin (OVA) through feeding followed by OVA challenges. In some study groups ATRA was orally administered concomitantly with OVA feeding either in the presence or absence of the retinoic acid receptor antagonist LE135. Lung CD4 ${ }^{+} \mathrm{T}$ cells were isolated from mice exposed to ATRA and/or OVA, and transferred to control mice. Airway hyperresponsiveness (AHR), cell counts and cytokine levels in bronchoalveolar lavage (BAL) fluid, and lung histology were assessed. Results: Concomitant administration of ATRA with OVA ameliorated AHR, airway eosinophilia, elevation of cytokines in BAL fluid and goblet cell metaplasia. The proportion of Treg cells in the lungs was increased in mice treated with OVA and ATRA, as compared to those treated with OVA only. Transfer of lung $C D 4^{+} T$ cells from mice treated with OVA and ATRA induced suppression of AHR and airway inflammation. LE135 completely reversed the effects of ATRA on AHR, airway allergic inflammation and the number of Treg cells in the lungs. Conclusion: These data suggested that oral administration of ATRA with OVA had the potential to enhance oral tolerance in this murine model of bronchial asthma. These effects were mediated, at least in part, by Treg cell expansion.

ㄷ) 2015 S. Karger AG, Basel

\section{Introduction}

Bronchial asthma is characterized by recurrent episodes of airway obstruction, airway hyperresponsiveness (AHR) to environmental stimuli, acute-on-chronic airway inflammation and structural changes in the airway walls [1]. Therefore, asthma management is based on avoiding exposure to allergens and controlling airway in-

\section{KARGER 125}

() 2015 S. Karger AG, Base

$1018-2438 / 15 / 1673-0167 \$ 39.50 / 0$

E-Mail karger@karger.com

www.karger.com/iaa
Correspondence to: Dr. Toshiyuki Koya

Division of Respiratory Medicine, Department of Homeostatic Regulation and Development, Niigata University Graduate School of Medical and Dental Sciences 1-754 Asahimachi-Dori, Niigata City 951-8510 (Japan)

E-Mail tkoya@med.niigata-u.ac.jp 
flammation. Currently, inhaled corticosteroids (ICS) are the most potent agents used to suppress airway inflammation. Indeed, there is substantial evidence for the efficacy of ICS in reducing airway inflammation [2], ameliorating AHR [3], airway remodeling [4], alleviating clinical symptoms [5] and improving prognosis [6]. However, several reports have indicated that ICS has little influence on disease history, even if disease severity is controlled [7, 8]. Moreover, the cost of asthma management is increasing rapidly.

Allergen (antigen)-specific immunotherapy is an immune-modifying therapy that has been recommended for the treatment of allergic rhinitis, venom hypersensitivity, some drug allergies, and mild bronchial asthma [9]. Oral administration of antigen is classically used to induce antigen-specific systemic immunotherapy, and is termed oral tolerance $[10,11]$. It is now widely accepted that the mechanisms of oral tolerance include not only anergy and apoptosis of antigen-specific $\mathrm{T}$ cells in the gut, but also active suppression through the induction of antigen-specific regulatory T (Treg) cells $[12,13]$. Most of the induced Treg cells are characterized by abundant production of immunosuppressive cytokines, such as interleukin (IL)-10 and transforming growth factor- $\beta$ (TGF- $\beta$ ), and expression of the transcription factor forkhead box P3 (Foxp3) [14].

We previously reported that both transfer of $T$ helper (Th) 17 cells or administration of IL-17 in the induction phase of oral tolerance abolished the therapeutic effects of oral tolerance by upregulating IL-6 production in Peyer's patch (PP) in a murine asthma model [15]. The vitamin A metabolite, retinoic acid (RA), has also been reported to enhance the expression of $\alpha 4 \beta 7$ integrin and $\mathrm{C}-\mathrm{C}$ chemokine receptor type 9 on T cells upon activation, imprinting them with gut tropism [16]. RA is a key regulator of TGF- $\beta$-dependent immune responses and was shown to inhibit IL-6-driven induction of proinflammatory Th17 cells and to promote anti-inflammatory Treg cell differentiation; peripheral conversion of $\mathrm{CD} 4^{+}$ $\mathrm{T}$ cells to Treg cells occurred primarily in gut-associated lymphoid tissue after oral exposure to antigen [17]. We therefore hypothesized that oral administration of alltrans RA (ATRA) along with the antigen would have the potential to enhance the effects of oral tolerance.

In the present study, we investigated the effect of ATRA on the induction of oral tolerance in a murine airway allergy model. Following challenges with ovalbumin (OVA), we evaluated AHR and allergic inflammation. We also investigated the modulating effects of transfer of $\mathrm{CD}^{+} \mathrm{T}$ cells from mice treated with oral ATRA and OVA to animals that did not receive these compounds orally, and assessed whether the effects of ATRA were mediated through the RA receptor (RAR) by using the RAR antagonist LE135.

\section{Materials and Methods}

\section{Animals}

Eight-week-old female BALB/c mice free of murine-specific pathogens were purchased from CLEA Japan Inc. (Tokyo, Japan). The animals were housed under specific pathogen-free conditions with a 12:12 h light:dark cycle. All experiments were conducted under a protocol approved by the Niigata University ethics committee for animal experiments.

\section{OVA-Induced Allergic Airway Inflammation and Oral}

\section{Tolerance}

Mice were sensitized on days 0 and 14 by intraperitoneal injection of $20 \mu \mathrm{g}$ OVA premixed with $2.25 \mathrm{mg}$ of $\mathrm{Al}(\mathrm{OH})_{3}$ in $100 \mu \mathrm{l}$ of phosphate-buffered saline (PBS). After sensitization, the animals were exposed to an OVA aerosol $(10 \mathrm{mg} / \mathrm{ml}$ in $0.9 \%$ saline) for 20 min on days 28,29 and 30 . From days 37 to 41 the mice were administered OVA ( $20 \mathrm{mg} /$ day or $100 \mathrm{mg} /$ day) by gavage once a day to induce oral tolerance, followed by OVA aerosol exposure (as described above) on days 48, 49 and 50. ATRA (250 $\mu \mathrm{g} /$ day) was administered orally along with OVA on days 37-41. Control mice received the same volume of PBS or ATRA alone by gavage. In some experiments, an RAR antagonist (LE135; $200 \mu \mathrm{g} /$ day) was administered intraperitoneally (i.p.) with oral ATRA + OVA on days 37-41. Twenty-four hours after the final OVA challenge, AHR was assessed and specimens of bronchoalveolar lavage (BAL) fluid, serum and lungs were collected for further analysis. Figure 1 shows a summary of the experimental protocols used in this study. In some mice, PP specimens were obtained $24 \mathrm{~h}$ after the final OVA feeding.

\section{Cell Preparations from Lungs and PPs and Transfer of Lung \\ Cells}

Lung cells were isolated as previously described [18] using collagenase digestion. Lung $\mathrm{CD} 4^{+} \mathrm{T}$ cells were purified from lung cells (purity $>98 \%$ ) using mouse CD4 Dynabeads ${ }^{\mathrm{TM}}$ (Invitrogen, Carlsbad, Calif., USA). These lung CD4 ${ }^{+} \mathrm{T}$ cells were then administered intravenously $\left(5 \times 10^{6}\right.$ cells/mouse) to OVA-sensitized mice, followed by further OVA challenges (fig. 1).

PPs were resected from the small intestine, passed through a steel mesh to remove any aggregates, and then washed twice with PBS containing $0.2 \% \mathrm{BSA}$ and $0.02 \% \mathrm{NaN}_{3}$ before use for flow cytometry.

\section{Airway Responsiveness}

AHR was assessed by measuring changes in respiratory resistance in response to increasing doses of inhaled methacholine (MCh) using the Flexivent system (SCIREQ, Montreal, Que., Canada), as previously reported [19].

\section{BAL Fluid and Lung Histology}

Immediately after the measurement of AHR, BAL was performed via a tracheal tube, as previously described [20]. Lungs were fixed in $10 \%$ formalin and processed for paraffin embedding. 
Fig. 1. Experimental protocols for OVA sensitization and challenge, including oral OVA administration, $\mathrm{CD} 4^{+} \mathrm{T}$ cell transfer, oral ATRA and LE135 administration, as described in Materials and Methods. a Mice were treated with oral OVA $(20 \mathrm{mg} /$ day or $100 \mathrm{mg} /$ day $)$ or oral OVA $(20 \mathrm{mg} /$ day) and ATRA for 5 days after the first OVA aerosol challenges, followed by secondary OVA challenges, and were sacrificed $24 \mathrm{~h}$ after the last challenge. b Lung $\mathrm{CD} 4^{+} \mathrm{T}$ cells were transferred from mice treated with oral OVA (20 mg/day) and ATRA to mice sensitized with OVA, followed by OVA challenges. c The RAR antagonist, LE135, was administered i.p. to mice treated with OVA and ATRA. N.S. = Normal saline.

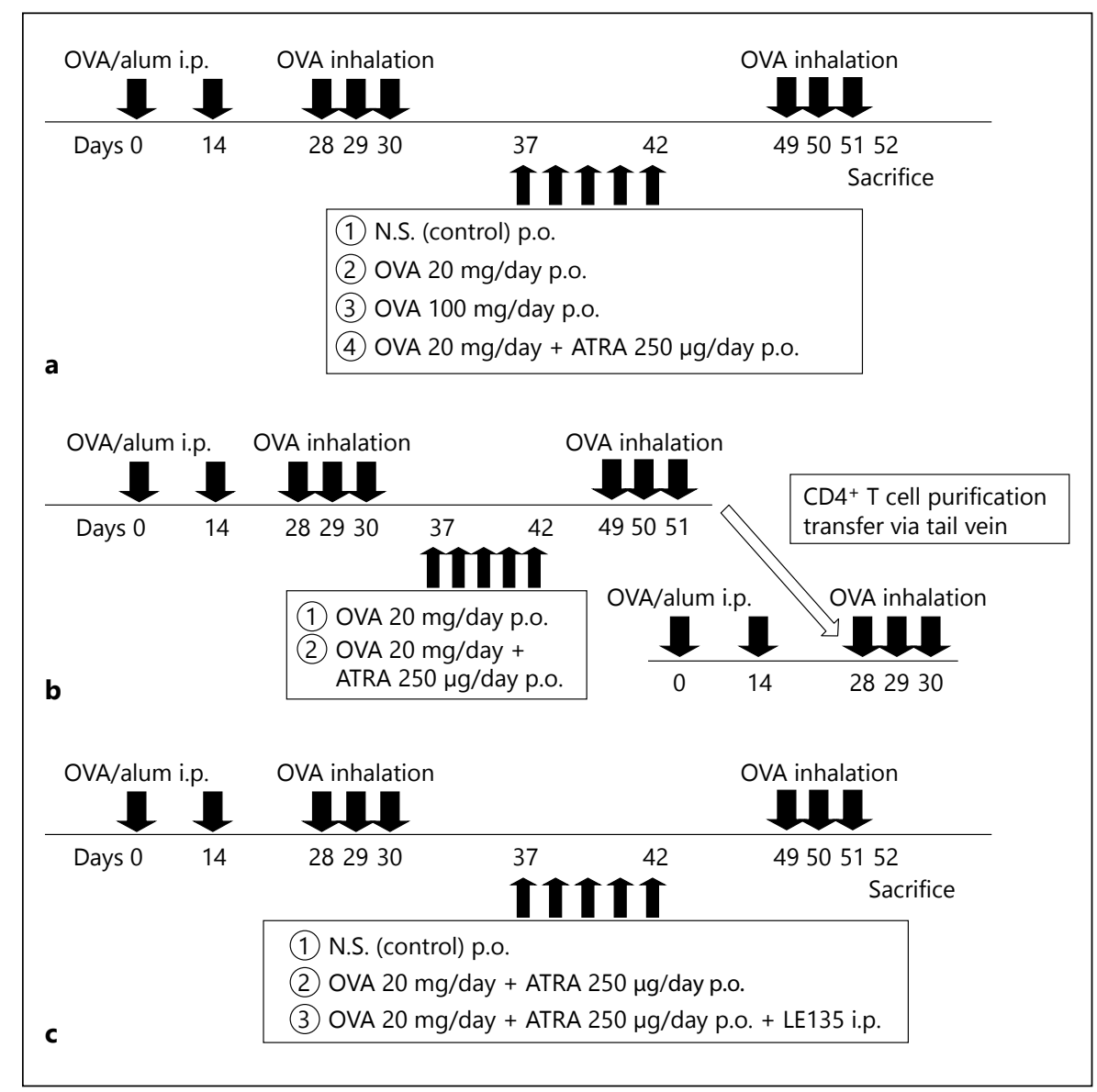

Mucus-containing goblet cells were detected by staining the paraffin sections ( $5 \mu \mathrm{m}$ thick) with periodic acid-Schiff (PAS). Histological analyses were performed as previously described [21].

\section{Flow Cytometry}

The surface phenotypes of the lung $\mathrm{CD} 4^{+} \mathrm{T}$ cells were analyzed by flow cytometry using a three-color immunofluorescence test. This employed monoclonal antibodies raised against CD4 (RM45), CD25 (PC61; both obtained from BD Biosciences, San Jose, Calif., USA) and Foxp3 (FJK-16S; eBioscience, San Diego, Calif., USA). After washing, the staining was analyzed on a FACSCalibur flow cytometer using CellQuest software (BD Biosciences).

\section{Measurement of Cytokines in BAL Fluid}

Supernatants from BAL fluid were stored at $-80^{\circ} \mathrm{C}$ prior to the measurement of cytokines. Enzyme-linked immunosorbent assay (ELISA) kits for the detection of IL-4, IL-5 and IL-17 were obtained from eBioscience. IL-10 and IL-13 ELISA kits were purchased from R\&D Systems (Minneapolis, Minn., USA).

\section{Statistical Analysis}

The Mann-Whitney $U$ test was used to determine the significance of group differences. Data were pooled from three independent experiments with 4 mice per group in each experiment $(\mathrm{n}=$ 12). Comparisons for all pairs were performed using the Kruskal-
Wallis test. Significance was assumed at $\mathrm{p}<0.05$ for all tests. Values for all measurements were expressed as the mean \pm standard error of the mean (SEM).

\section{Results}

\section{Effect of ATRA on AHR, Airway Inflammation and} Airway Remodeling

We initially examined the effects of oral OVA administration in a murine airway allergy model. Mice that were treated with $100 \mathrm{mg} /$ day OVA showed reduced AHR in response to MCh (fig. 2a), reduced airway eosinophilia (fig. 2b), lower levels of IL-5 and IL-13 in BAL fluid (fig. 2c), and reduced mucus production in the bronchi (fig. 2d, e) as compared with mice treated with PBS alone. On the other hand, $20 \mathrm{mg} /$ day OVA did not induce a significant reduction of AHR, airway eosinophilia, Th2 cytokine production in BAL fluid and goblet cell metaplasia (fig. 2). However, administration of ATRA in addition to $20 \mathrm{mg} /$ day OVA reduced AHR to a similar level to that 


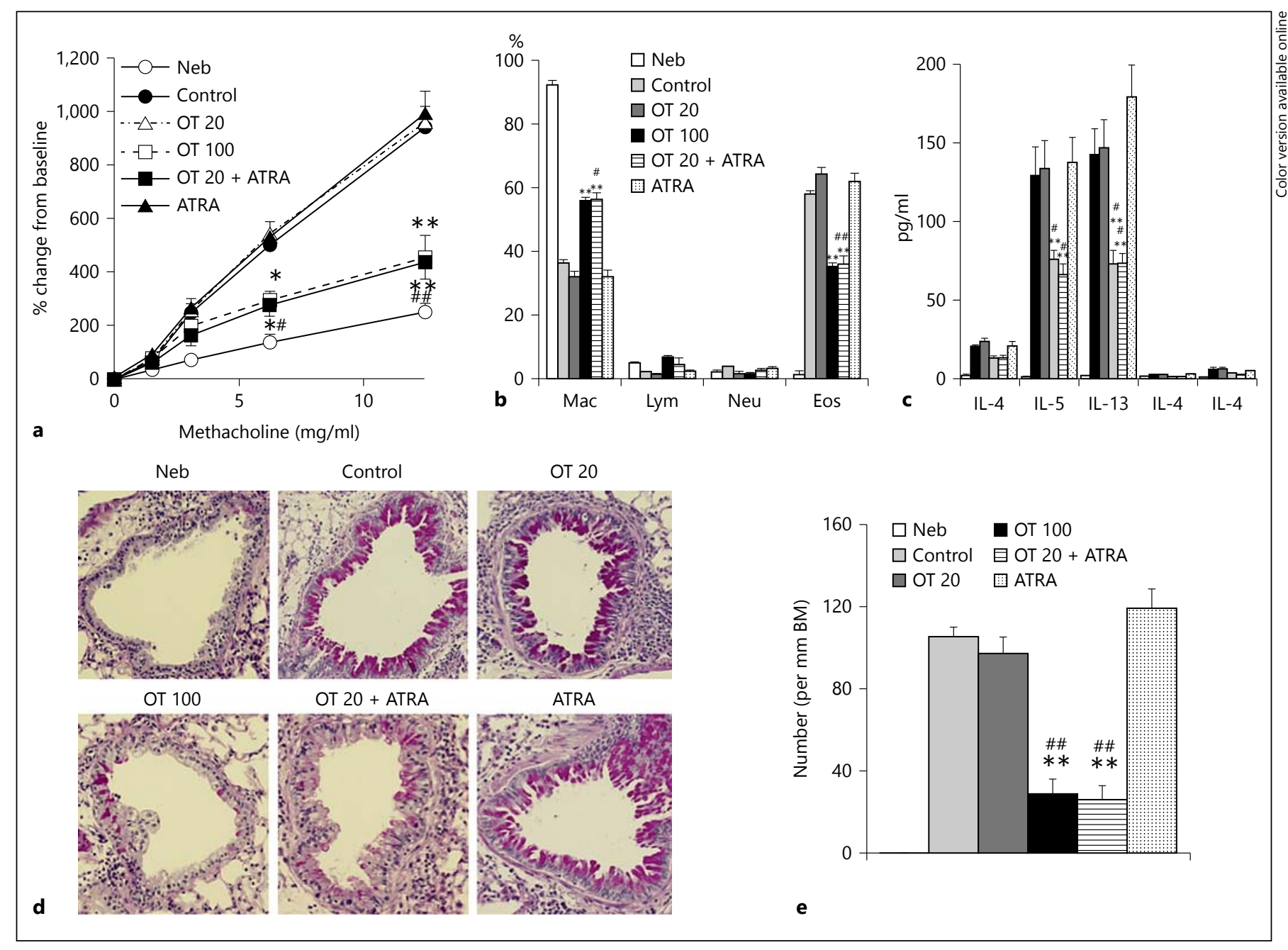

Fig. 2. The effects of ATRA on AHR, airway allergic inflammation and goblet cell metaplasia. a Changes in airway resistance in response to the indicated concentrations of nebulized MCh. b Changes in cell composition in BAL fluid. c Levels of the indicated cytokines in BAL fluid. d Representative PAS staining of lung sections obtained $24 \mathrm{~h}$ after the last OVA challenge. Original magnification $\times 100$. e Quantitative analysis of PAS-positive cells in bronchial tissue. Control: OVA-sensitized mice with OVA challenges; OT 20: OVA-sensitized mice with OVA challenges + oral

observed in animals administered $100 \mathrm{mg} /$ day OVA (fig. 2a). Airway eosinophilia in the ATRA plus $20 \mathrm{mg} /$ day OVA group was significantly decreased in comparison to the group that received OVA only (fig. $2 \mathrm{~b}$ ). The IL-5 and IL-13 levels in BAL fluid were decreased in mice that were treated with ATRA plus $20 \mathrm{mg} /$ day OVA, as compared to mice receiving only $20 \mathrm{mg} /$ day OVA only (fig. 2c). The number of PAS-positive cells was also significantly lower in the ATRA plus $20 \mathrm{mg} /$ day OVA group and was similar to the number observed in mice admin-
OVA (20 mg/day); OT 100: OVA-sensitized mice with OVA challenges + oral OVA (100 mg/day); OT 20 + ATRA: OVA-sensitized mice with OVA challenges + oral OVA ( $20 \mathrm{mg} /$ day) and ATRA $(250 \mu \mathrm{g} /$ day); ATRA: OVA-sensitized mice with OVA challenges + ATRA $(250 \mu \mathrm{g} /$ day $)$. Data represent the mean \pm SEM. ${ }^{*} \mathrm{p}<$ $0.05,{ }^{* *} \mathrm{p}<0.01$ compared to the control group; ${ }^{\#} \mathrm{p}<0.05$, ${ }^{\# \#} \mathrm{p}<$ 0.01 compared to the OT 20 group. Mac $=$ Macrophages; Lym = lymphocytes; $\mathrm{Neu}=$ neutrophils; Eos = eosinophils; $\mathrm{BM}=$ basement membrane; $\mathrm{Neb}=$ nonsensitized mice with OVA challenges .

istered $100 \mathrm{mg}$ /day OVA (fig. 2d, e). Interestingly, oral administration of ATRA without OVA had little effect on AHR, airway eosinophilia, cytokine levels in BAL fluid, or goblet cell metaplasia (fig. 2). Oral administration of ATRA in combination with $100 \mathrm{mg} /$ day OVA feeding had no additional effects on AHR and airway inflammation compared to $100 \mathrm{mg}$ /day OVA feeding alone (data not shown).

A 250- $\mu$ g dose of ATRA was selected based on a preliminary investigation. We investigated the dose depen- 

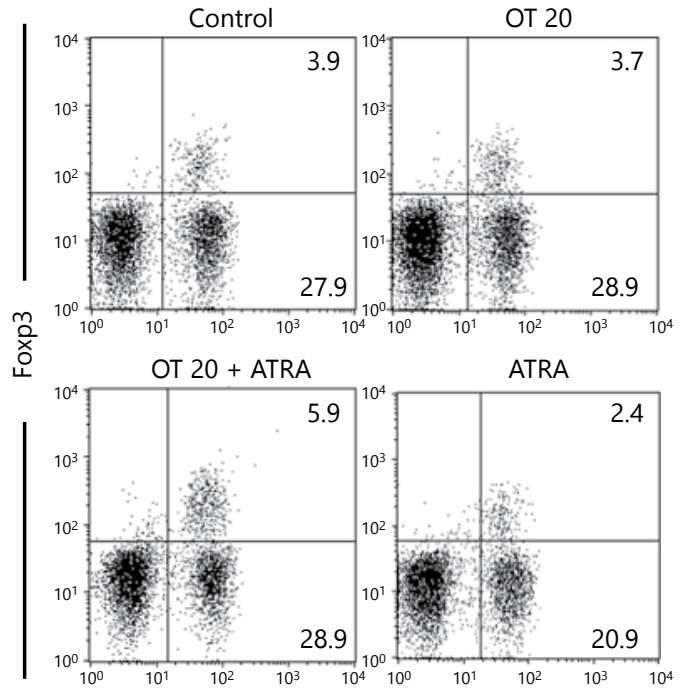

a

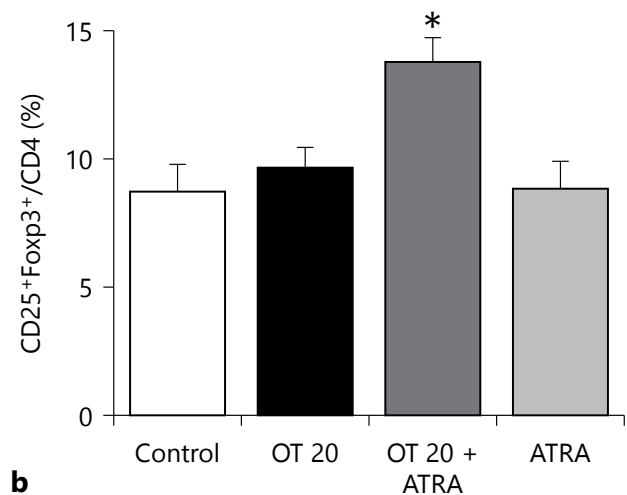

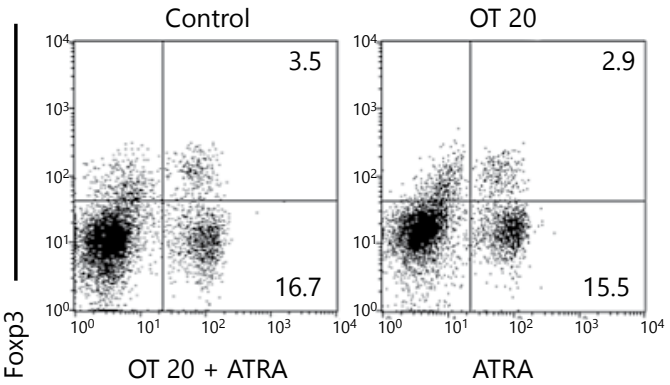

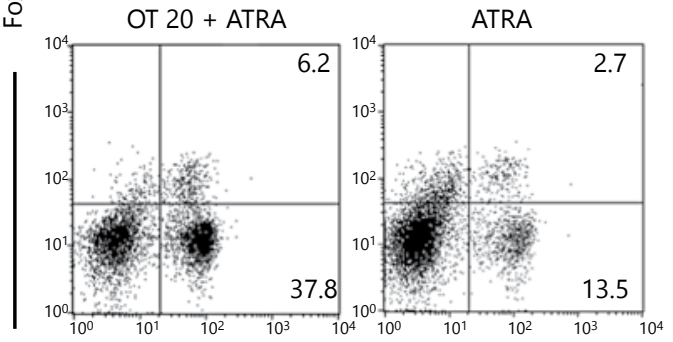

C

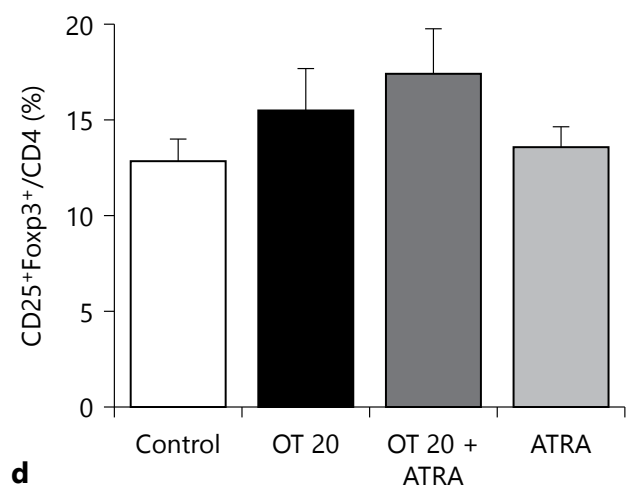

Fig. 3. Analysis of lung and PP cells using flow cytometry. a Representative CD 4 and Foxp 3 expression in lung cells. b CD $25^{+}$Foxp $3^{+}$ cells, expressed as a percentage of lung $\mathrm{CD} 4^{+}$cells. $\mathbf{c}$ Representative CD 4 and Foxp 3 expression in PP cells. d CD $25^{+}$Foxp $3^{+}$PP cells, expressed as a percentage of $\mathrm{CD} 4^{+} \mathrm{PP}$ cells. Control: OVA-sensitized mice with OVA challenges; OT 20: OVA-sensitized mice

dency of the effects of ATRA on AHR, airway inflammation and goblet metaplasia and found that $250 \mu \mathrm{g}$ of ATRA was superior to $50 \mu \mathrm{g}$ and $1,000 \mu \mathrm{g}$ (online suppl. fig. 1; for all online suppl. material, see www.karger.com/ doi/10.1159/000437326).

\section{Comparison of Lung and PP Foxp3-Positive Treg \\ Expansion}

Previous reports described the potency of Treg cell induction by RA in vitro and in vivo $[17,22,23]$. To investigate the expansion of Treg cells in the lungs, cells were harvested and stained for CD4, CD25 and Foxp3. As with OVA challenges + oral OVA (20 mg/day); OT 20 + ATRA: OVA-sensitized mice with OVA challenges + oral OVA (20 mg/ day) and ATRA $(250 \mu \mathrm{g} /$ day); ATRA: OVA-sensitized mice with OVA challenges + ATRA $(250 \mu \mathrm{g} /$ day $)$. Data represent the mean \pm SEM from three independent experiments $(\mathrm{n}=6){ }^{*} \mathrm{p}<0.05 \mathrm{com}-$ pared to the OT 20 group.

shown in figure $3 \mathrm{a}$ and $\mathrm{b}$, the ratio of Foxp $3^{+}$Treg cells to the total count of $\mathrm{CD} 4^{+} \mathrm{T}$ cells was increased in the ATRA plus $20 \mathrm{mg}$ /day OVA group as compared to the $20 \mathrm{mg} /$ day OVA group or ATRA alone.

To determine the effects of combined OVA and ATRA treatment on the gut, cells were harvested from PPs of treated mice and stained for CD4, CD25 and Foxp3. The ratio of Foxp $3^{+}$Treg cells to the total count of $\mathrm{CD} 4^{+} \mathrm{T}$ cells was not significantly increased by the ATRA plus $20 \mathrm{mg} /$ day OVA treatment as compared to the $20 \mathrm{mg} /$ day OVA group or the group that received ATRA alone (fig. 3c, d). 


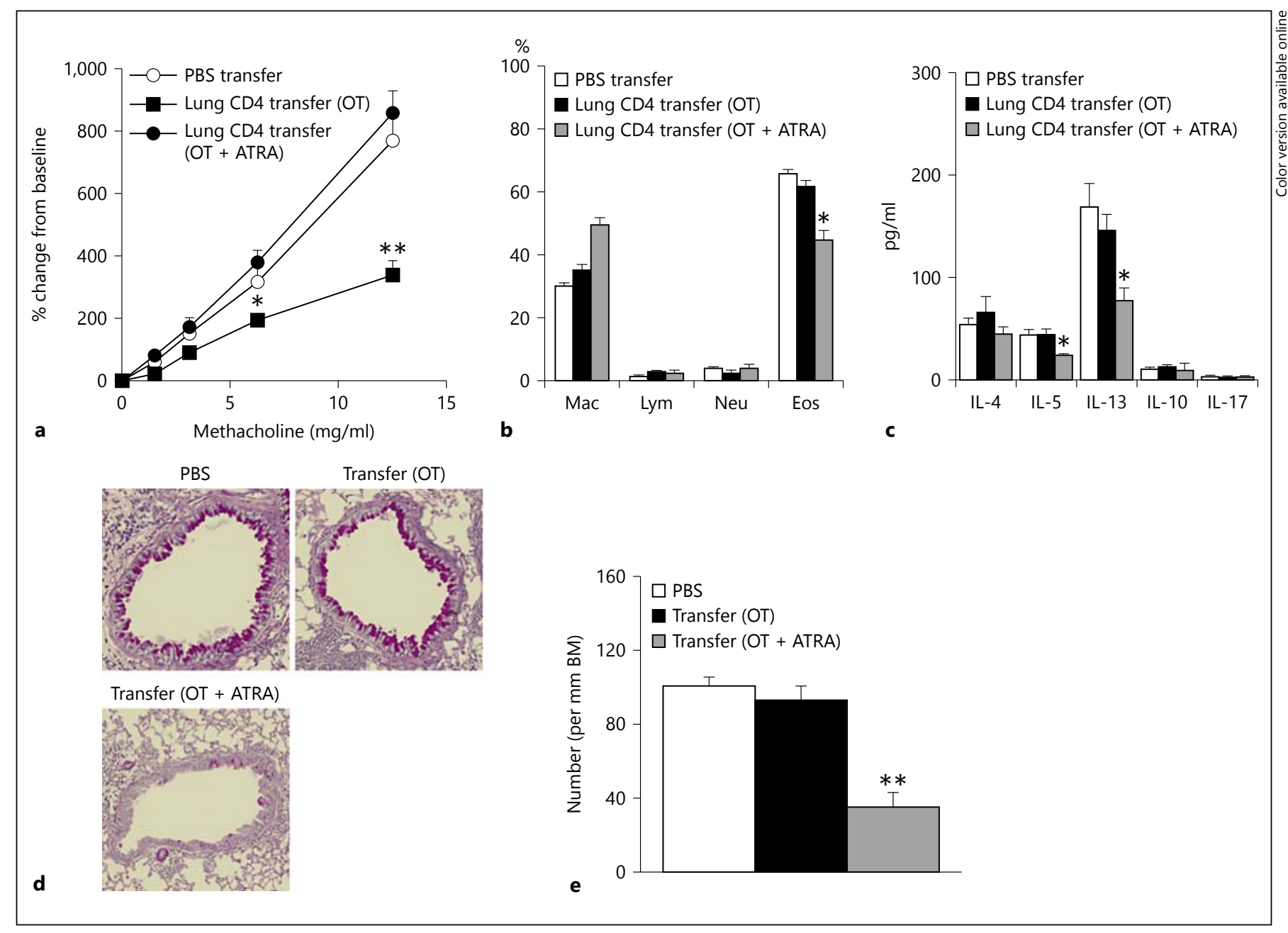

Fig. 4. The effects of lung $\mathrm{CD}^{+} \mathrm{T}$ cells from OVA-sensitized mice treated with oral ATRA and/or OVA (and OVA challenges) on AHR, airway allergic inflammation and goblet cell metaplasia. a Changes in airway resistance in response to the indicated concentrations of nebulized MCh. $\mathbf{b}$ Changes in the cell composition of BAL fluid. c Levels of the indicated cytokines in BAL fluid. d Representative PAS staining of lung sections obtained $24 \mathrm{~h}$ after the last OVA challenge. Original magnification $\times 100$. e Quantita-

Effects of Lung CD4 $4^{+}$T Cell Transfer on AHR, Airway Inflammation and Airway Remodeling

To investigate whether $\mathrm{CD} 4^{+} \mathrm{T}$ cells had the potential to modify AHR and allergic airway inflammation, lung $\mathrm{CD}^{+} \mathrm{T}$ cells were transferred from mice that received either ATRA and $20 \mathrm{mg}$ /day OVA or only $20 \mathrm{mg}$ /day OVA to control mice sensitized with OVA; these animals then underwent additional OVA exposures. Transfer of these cells from mice exposed to ATRA and OVA suppressed AHR to MCh, whereas transfer from mice that received OVA alone did not suppress AHR as com- tive analysis of PAS-positive cells in bronchial tissue. Transfer (OT): transfer of $\mathrm{CD}^{+}$lung $\mathrm{T}$ cells from mice treated with OVA (20 mg/day); transfer (OT + ATRA): transfer of $\mathrm{CD} 4^{+}$lung T cells from mice treated with OVA $(20 \mathrm{mg} /$ day $)$ and ATRA $(250 \mu \mathrm{g} /$ day). Data represent the mean \pm SEM. ${ }^{*} \mathrm{p}<0.05,{ }^{* *} \mathrm{p}<0.01 \mathrm{com}-$ pared to the transfer $(\mathrm{OT})$ group. $\mathrm{Mac}=$ Macrophages; $\mathrm{Lym}=$ lymphocytes; $\mathrm{Neu}=$ neutrophils; $\mathrm{Eos}=$ eosinophils; $\mathrm{BM}=$ basement membrane.

pared to PBS-treated mice (fig. 4a). The percentage of eosinophils in BAL fluid was decreased in recipients of lung $\mathrm{CD} 4^{+} \mathrm{T}$ cells from mice that received ATRA and OVA as compared to mice that only received OVA (fig. 4b). Transfer of lung CD4 ${ }^{+} \mathrm{T}$ cells from mice treated with ATRA and OVA suppressed IL-5 and IL-13 levels in BAL fluid (fig. 4c). Goblet cell metaplasia was dramatically reduced in recipients of lung $\mathrm{CD} 4^{+} \mathrm{T}$ cells from mice that received ATRA and OVA as compared to recipients of cells from mice that only received OVA (fig. 4d, e). 


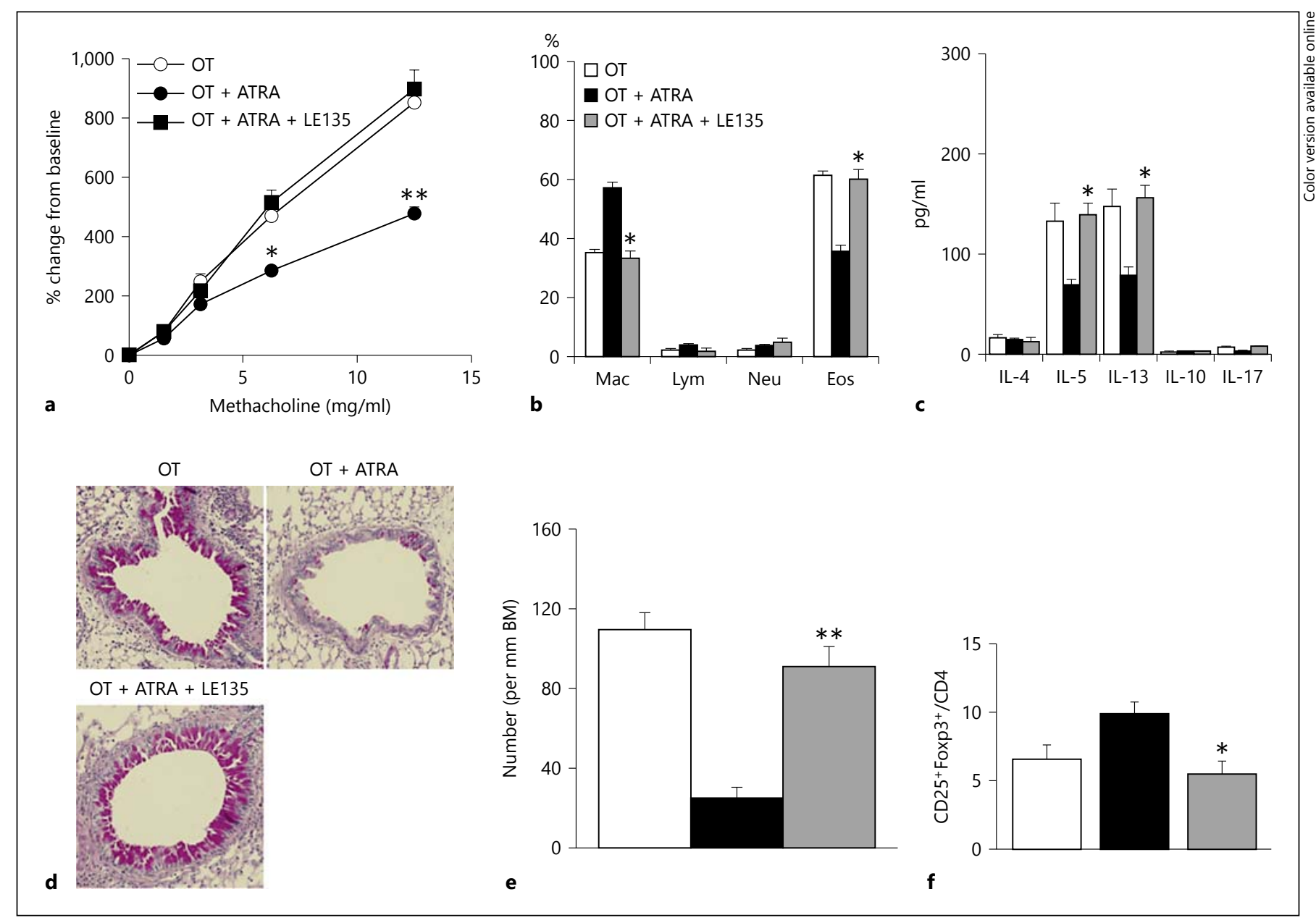

Fig. 5. Effects of LE135 on AHR, airway allergic inflammation and goblet cell metaplasia. a Changes in airway resistance in response to the indicated concentrations of nebulized MCh. $\mathbf{b}$ Cell composition in BAL fluid. c Cytokine levels in BAL fluid. $\mathbf{d}$ Representative data of PAS staining of lung sections obtained $24 \mathrm{~h}$ after the last OVA challenge. Original magnification $\times 100$. e Quantitative analysis of PAS-positive cells in bronchial tissue. $\mathbf{f} \mathrm{CD} 25^{+} \mathrm{Foxp} 3^{+}$lung cells, expressed as a percentage of lung $\mathrm{CD} 4^{+}$cells. OT: OVA-sen-

\section{Effects of LE135 on AHR, Airway Inflammation and}

\section{Airway Remodeling}

To determine whether the effects of ATRA were mediated by the RAR, an antagonist of this receptor (LE135) was administered i.p. concomitantly with OVA and ATRA. As shown in figure $5 \mathrm{a}, \mathrm{LE} 135$ reversed the inhibitory effects of ATRA. LE135 also increased the percentage of eosinophils and the levels of IL-5 and IL-13 in BAL fluid (fig. 5b, c). Goblet cell metaplasia was greater in mice that received LE135 with ATRA and OVA, as compared to those receiving ATRA and OVA only (fig. 5d, e). Moreover, the ratio of Foxp $3^{+}$Treg cells to the total count of $\mathrm{CD} 4^{+} \mathrm{T}$ cells was sitized mice with OVA challenges + oral OVA (20 mg/day); OT + ATRA: OVA-sensitized mice with OVA challenges + oral OVA $(20 \mathrm{mg} /$ day $)$ and ATRA (250 $\mu \mathrm{g} /$ day $)$; OT + ATRA + LE135: OVAsensitized mice with OVA challenges + oral OVA ( $20 \mathrm{mg} /$ day $)$ and ATRA $(250 \mu \mathrm{g} /$ day $)+\operatorname{LE} 135(200 \mu \mathrm{g} /$ day $)$. Data represent the mean \pm SEM. ${ }^{*} \mathrm{p}<0.05,{ }^{* *} \mathrm{p}<0.01$ compared to the OVA + ATRA group. $\mathrm{Mac}=$ Macrophages; $\mathrm{Lym}=$ lymphocytes; $\mathrm{Neu}=$ neutrophils; Eos = eosinophils; $\mathrm{BM}=$ basement membrane.

significantly decreased in the group that received LE135, OVA and ATRA, as compared to the group that only received OVA and ATRA (fig. 5f). In mice that received LE135 without ATRA and OVA, there was no significant change in AHR or airway eosinophilia (data not shown).

\section{Discussion}

The present study found that ATRA augmented the oral tolerance induced by OVA. LE135-mediated RAR blockade reversed the inhibitory effects of ATRA, indi- 
cating the involvement of this receptor. We also demonstrated that the increase of lung Treg cells played a role, at least in part, in the suppression of AHR, airway eosinophilia and goblet cell metaplasia. This represented a novel approach to the investigation of the function of ATRA in a model of asthma.

In this study, oral administration of ATRA, in addition to OVA, enhanced the induction of oral tolerance. Orally administered ATRA may be absorbed in the gut mucosa and could subsequently modulate the immune system. Interestingly, our data suggested that the therapeutic effects of ATRA in this oral tolerance model required concomitant administration of antigen, because administration of ATRA without OVA had no effects on the therapeutic outcomes. It is presumably important for local antigen-presenting cells to recognize antigens under RArich milieu for upregulation of oral tolerance. Indeed, dendritic cells produce RA from dietary vitamin A using retinaldehyde dehydrogenase; they also express RAR and have been shown to respond to RA [24]. Moreover, intraperitoneal injection of ATRA in addition to oral OVA was reported to be ineffective for the amelioration of AHR and airway allergic inflammation because ATRA administered by this route appeared to be rapidly metabolized in the liver [25].

RA plays an indispensable role in the gut by modulating $\mathrm{CD}_{103^{+}}$dendritic cells $[26,27]$ and $\mathrm{CD} 4^{+} \mathrm{T}$ cells $[16]$. In particular, RA is known to be a strong inducer of Tregs, an effect mediated by enhanced TGF- $\beta$-driven phosphorylation of SMAD3 $[28,29]$, inhibition of CD $4^{+} C D 44^{\text {high }}$ memory T cells [30], or induction of histone $\mathrm{H} 4$ acetylation at the Foxp3 locus [31]. In this study, lung Tregs expressing CD4, CD25 and Foxp3 were increased by exposure to oral OVA, ATRA and subsequent aerosol OVA challenges; lung $\mathrm{CD}^{+} \mathrm{T}$ cells from mice treated with OVA and ATRA also sustained the suppression of AHR, airway inflammation and goblet cell metaplasia in mice sensitized and challenged with OVA. According to previous studies employing adoptive transfer of $\mathrm{CD} 4^{+} \mathrm{CD} 25^{+}$ $\mathrm{T}$ cells or administration of anti-CD25 antibody for the depletion of Tregs, naturally occurring and induced Treg cells both have the potential to modulate AHR and airway allergic inflammation [32-34]. In the present study, it was not technically possible to isolate adequate numbers of $\mathrm{CD} 4^{+} \mathrm{CD} 25^{+}$cells and we therefore transferred the entire $\mathrm{CD} 4^{+}$cell population. Our data indicated that these $\mathrm{CD} 4^{+}$ $\mathrm{T}$ cells were able to sustain the inhibitory effects on AHR and airway inflammation, suggesting that the $\mathrm{CD}^{+}{ }^{+} \mathrm{T}$ cells transferred in the present study contained a sufficient number of regulatory features.
In our previous study, AHR and allergic inflammation were ameliorated through oral antigen-mediated induction of gut Treg cells, inhibited by endogenous and exogenous IL-17 [15]. Oral administration of ATRA with OVA was thought to induce gut Treg cells, which presumably moved to the lung after the antigen challenges. However, in the current study, the number of Treg cells in PPs was not significantly increased after oral administration of ATRA in addition to OVA feeding compared to OVA feeding alone. Although our results did not conclusively demonstrate that the Treg cells found in the lung originated in the gut, they showed that oral administration of ATRA in addition to OVA induced Treg cells in the lung after OVA challenges. Future work should be conducted to investigate the transfer of Treg cells using cells isolated from the gut.

Several reports have described the inhibitory effects of oral antigen administration on airway allergic inflammation $[35,36]$. These studies involved the administration of antigen prior to the sensitization or challenge phases. Oral tolerance is difficult to induce after the establishment of a robust immune system; indeed, our data showed that a lower dose (20 mg/day) of oral OVA had much less effect on AHR, airway inflammation or goblet cell metaplasia than the higher dose (100 mg/day). However, as bronchial asthma patients never receive immunotherapy before the occurrence of their disease in the clinical setting, it is worth noting that the addition of ATRA could augment the effects of oral tolerance in this therapeutic model.

Although RA is involved in modulating the function and maturation of eosinophils [37], basophils [38] and mast cells [39], as well as dendritic cells and T cells, there are few reports describing its effects on airway allergic inflammation. Maret et al. [40] reported that systemic administration of liposome-encapsulated ATRA during the sensitization phase induced more sustained levels of RA (as compared with a conventional ATRA formulation); this augmented airway eosinophilia, the levels of Th2 cytokines and chemokines, and serum IgE levels. On the other hand, systemic administration of ATRA from immunization to the challenge phases ameliorated airway allergic inflammation by modulating Th2 differentiation [41]. In the present study, oral administration of ATRA concomitant to OVA augmented the oral tolerance. From previous reports, ATRA has multiple effects for allergic models, and this study represents a unique approach to investigating the novel functions of ATRA.

In summary, we investigated the role of ATRA in modulating the induction of oral tolerance in a murine airway allergy model. After challenges with OVA, we 
evaluated AHR and allergic inflammation. We also investigated the modulating effects of $\mathrm{CD} 4^{+} \mathrm{T}$ cell transfer from mice that were treated with oral ATRA and/or OVA, and assessed whether the effects of ATRA were mediated through the RAR using LE135. These data suggested that oral administration of ATRA concomitant with antigen was useful for augmenting the effects of oral tolerance via the modulation of Treg cell induction in this murine asthma model.

\section{Acknowledgements}

The authors are grateful for the expert help of Dr. Naofumi Imai, Ms. Keiko Yamagiwa and Ms. Kaori Takahashi for performing the histological studies and caring for the animals.

\section{Conflict of Interest}

The authors declare that they have no competing interests.

\section{References}

1 Busse WW, Lemanske RF Jr: Asthma. New Engl J Med 2001;344:350-362.

2 Jeffery PK, Godfrey RW, Adelroth E, Nelson F, Rogers A, Johansson SA: Effects of treatment on airway inflammation and thickening of basement membrane reticular collagen in asthma: a quantitative light and electron microscopic study. Am Rev Respir Dis 1992;145: 890-899.

3 Haahtela T, Jarvinen M, Kava T, Kiviranta K, Koskinen S, Lehtonen K, Nikander K, Persson $\mathrm{T}$, Selroos O, Sovijarvi A, et al: Effects of reducing or discontinuing inhaled budesonide in patients with mild asthma. New Engl J Med 1994;331:700-705.

4 Olivieri D, Chetta A, Del Donno M, Bertorelli G, Casalini A, Pesci A, Testi R, Foresi A: Effect of short-term treatment with low-dose inhaled fluticasone propionate on airway inflammation and remodeling in mild asthma: a placebo-controlled study. Am J Respir Crit Care Med 1997;155:1864-1871.

5 Juniper EF, Kline PA, Vanzieleghem MA, Ramsdale EH, O’Byrne PM, Hargreave FE: Effect of long-term treatment with an inhaled corticosteroid (budesonide) on airway hyperresponsiveness and clinical asthma in nonsteroid-dependent asthmatics. Am Rev Respir Dis $1990 ; 142: 832-836$.

6 Suissa S, Ernst P, Benayoun S, Baltzan M, Cai B: Low-dose inhaled corticosteroids and the prevention of death from asthma. New Engl J Med 2000;343:332-336.

7 Guilbert TW, Morgan WJ, Zeiger RS, Mauger DT, Boehmer SJ, Szefler SJ, Bacharier LB, Lemanske RF Jr, Strunk RC, Allen DB, Bloomberg GR, Heldt G, Krawiec M, Larsen G, Liu AH, Chinchilli VM, Sorkness CA, Taussig LM, Martinez FD: Long-term inhaled corticosteroids in preschool children at high risk for asthma. New Engl J Med 2006;354:19851997.

8 Bisgaard H, Hermansen MN, Loland L, Halkjaer LB, Buchvald F: Intermittent inhaled corticosteroids in infants with episodic wheezing. New Engl J Med 2006;354:1998-2005.

9 Holgate ST, Polosa R: Treatment strategies for allergy and asthma. Nat Rev Immunol 2008;8: 218-230.
10 Smith KM, Eaton AD, Finlayson LM, Garside P: Oral tolerance. Am J Respir Crit Care Med 2000;162:S175-S178.

11 Weiner HL, Friedman A, Miller A, Khoury SJ, al-Sabbagh A, Santos L, Sayegh M, Nussenblatt RB, Trentham DE, Hafler DA: Oral tolerance: immunologic mechanisms and treatment of animal and human organ-specific autoimmune diseases by oral administration of autoantigens. Annu Rev Immunol 1994;12: 809-837.

12 Kraal G, Samsom JN, Mebius RE: The importance of regional lymph nodes for mucosal tolerance. Immunol Rev 2006;213:119-130.

13 Faria AM, Weiner HL: Oral tolerance: therapeutic implications for autoimmune diseases. Clin Dev Immunol 2006;13:143-157.

14 Tsuji NM, Kosaka A: Oral tolerance: intestinal homeostasis and antigen-specific regulatory T cells. Trends Immunol 2008;29:532540 .

15 Kawakami H, Koya T, Kagamu H, Kimura Y, Sakamoto H, Yamabayashi C, Furukawa T, Sakagami T, Miyabayashi T, Hasegawa T, Suzuki E, Narita I: IL-17 eliminates therapeutic effects of oral tolerance in murine airway allergic inflammation. Clin Exp Allergy 2012; 42:946-957.

16 Iwata M, Hirakiyama A, Eshima Y, Kagechika H, Kato C, Song SY: Retinoic acid imprints gut-homing specificity on T cells. Immunity 2004;21:527-538.

17 Mucida D, Park Y, Kim G, Turovskaya O, Scott I, Kronenberg M, Cheroutre H: Reciprocal $\mathrm{T}_{\mathrm{H}} 17$ and regulatory $\mathrm{T}$ cell differentiation mediated by retinoic acid. Science 2007; 317:256-260.

18 Koya T, Matsuda H, Takeda K, Matsubara S, Miyahara N, Balhorn A, Dakhama A, Gelfand EW: IL-10-treated dendritic cells decrease airway hyperresponsiveness and airway inflammation in mice. J Allergy Clin Immunol 2007;119:1241-1250.

19 Hayashi M, Koya T, Kawakami H, Sakagami T, Hasegawa T, Kagamu H, Takada T, Sakai Y, Suzuki E, Gelfand EW, Gejyo F: A prostacyclin agonist with thromboxane inhibitory activity for airway allergic inflammation in mice. Clin Exp Allergy 2010;40:317-326.
20 Koya T, Takeda K, Kodama T, Miyahara N, Matsubara S, Balhorn A, Joetham A, Dakhama A, Gelfand EW: RANTES (CCL5) regulates airway responsiveness after repeated allergen challenge. Am J Respir Cell Mol Biol 2006;35:147-154.

21 Koya T, Kodama T, Takeda K, Miyahara N, Yang ES, Taube C, Joetham A, Park JW, Dakhama A, Gelfand EW: Importance of myeloid dendritic cells in persistent airway disease after repeated allergen exposure. Am J Respir Crit Care Med 2006;173:42-55.

22 Kwok SK, Park MK, Cho ML, Oh HJ, Park EM, Lee DG, Lee J, Kim HY, Park SH: Retinoic acid attenuates rheumatoid inflammation in mice. J Immunol 2012;189:1062-1071.

$23 \mathrm{Lu} \mathrm{L}$, Lan Q, Li Z, Zhou X, Gu J, Li Q, Wang J, Chen M, Liu Y, Shen Y, Brand DD, Ryffel B, Horwitz DA, Quismorio FP, Liu Z, Li B, Olsen NJ, Zheng SG: Critical role of all-trans retinoic acid in stabilizing human natural regulatory $\mathrm{T}$ cells under inflammatory conditions. Proc Natl Acad Sci U S A 2014;111:E3432-E3440.

24 Manicassamy S, Ravindran R, Deng J, Oluoch H, Denning TL, Kasturi SP, Rosenthal KM, Evavold BD, Pulendran B: Toll-like receptor 2-dependent induction of vitamin a-metabolizing enzymes in dendritic cells promotes $\mathrm{T}$ regulatory responses and inhibits autoimmunity. Nat Med 2009;15:401-409.

25 Mehta K, Sadeghi T, McQueen T, Lopez-Berestein G: Liposome encapsulation circumvents the hepatic clearance mechanisms of alltrans-retinoic acid. Leuk Res 1994;18:587-596.

26 Klebanoff CA, Spencer SP, Torabi-Parizi P, Grainger JR, Roychoudhuri R, Ji Y, Sukumar M, Muranski P, Scott CD, Hall JA, Ferreyra GA, Leonardi AJ, Borman ZA, Wang J, Palmer DC, Wilhelm C, Cai R, Sun J, Napoli JL, Danner RL, Gattinoni L, Belkaid Y, Restifo NP: Retinoic acid controls the homeostasis of pre-cDC-derived splenic and intestinal dendritic cells. J Exp Med 2013;210:1961-1976.

27 Beijer MR, Molenaar R, Goverse G, Mebius RE, Kraal G, den Haan JM: A crucial role for retinoic acid in the development of notch-dependent murine splenic $\mathrm{CD}^{-} \mathrm{CD}^{-}$and $\mathrm{CD} 4^{+}$dendritic cells. Eur J Immunol 2013;43: 1608-1616. 
28 Xiao S, Jin H, Korn T, Liu SM, Oukka M, Lim B, Kuchroo VK: Retinoic acid increases Foxp $3^{+}$regulatory $\mathrm{T}$ cells and inhibits development of Th17 cells by enhancing TGF- $\beta$ driven smad3 signaling and inhibiting IL-6 and IL-23 receptor expression. J Immunol 2008;181:2277-2284.

29 Nolting J, Daniel C, Reuter S, Stuelten C, Li P, Sucov H, Kim BG, Letterio JJ, Kretschmer K, Kim HJ, von Boehmer H: Retinoic acid can enhance conversion of naive into regulatory $\mathrm{T}$ cells independently of secreted cytokines. J Exp Med 2009;206:2131-2139.

30 Takeuchi H, Yokota-Nakatsuma A, Ohoka Y, Kagechika H, Kato C, Song SY, Iwata M: Retinoid $\mathrm{X}$ receptor agonists modulate Foxp $3^{+}$ regulatory $\mathrm{T}$ cell and Th17 cell differentiation with differential dependence on retinoic acid receptor activation. J Immunol 2013;191: 3725-3733.

31 Kang SG, Lim HW, Andrisani OM, Broxmeyer HE, Kim CH: Vitamin a metabolites induce gut-homing Foxp $3^{+}$regulatory T cells. J Immunol 2007;179:3724-3733.

32 Joetham A, Takeda K, Taube C, Miyahara N, Matsubara S, Koya T, Rha YH, Dakhama A, Gelfand EW: Naturally occurring lung
$\mathrm{CD} 4^{+} \mathrm{CD} 25^{+} \mathrm{T}$ cell regulation of airway allergic responses depends on IL-10 induction of TGF- $\beta$. J Immunol 2007;178:1433-1442.

33 Boudousquie C, Pellaton C, Barbier N, Spertini F: $\mathrm{CD} 4^{+} \mathrm{CD} 25^{+} \mathrm{T}$ cell depletion impairs tolerance induction in a murine model of asthma. Clin Exp Allergy 2009;39:1415-1426.

$34 \mathrm{Xu} \mathrm{W}$, Lan Q, Chen M, Chen H, Zhu N, Zhou X, Wang J, Fan H, Yan CS, Kuang JL, Warburton D, Togbe D, Ryffel B, Zheng SG, Shi W: Adoptive transfer of induced-Treg cells effectively attenuates murine airway allergic inflammation. PLoS One 2012;7:e40314.

35 Russo M, Nahori MA, Lefort J, Gomes E, de Castro Keller A, Rodriguez D, Ribeiro OG, Adriouch S, Gallois V, de Faria AM, Vargaftig BB: Suppression of asthma-like responses in different mouse strains by oral tolerance. Am J Respir Cell Mol Biol 2001; 24:518-526.

36 Nagatani K, Dohi M, To Y, Tanaka R, Okunishi K, Nakagome K, Sagawa K, Tanno Y, Komagata Y, Yamamoto K: Splenic dendritic cells induced by oral antigen administration are important for the transfer of oral tolerance in an experimental model of asthma. J Immunol 2006; 176:1481-1489.
37 Denburg JA, Sehmi R, Upham J: Regulation of IL-5 receptor on eosinophil progenitors in allergic inflammation: role of retinoic acid. Int Arch Allergy Immunol 2001;124:246-248.

38 Spiegl N, Didichenko S, McCaffery P, Langen $\mathrm{H}$, Dahinden CA: Human basophils activated by mast cell-derived IL-3 express retinaldehyde dehydrogenase-II and produce the immunoregulatory mediator retinoic acid. Blood 2008;112:3762-3771.

39 Kinoshita T, Koike K, Mwamtemi HH, Ito S, Ishida S, Nakazawa Y, Kurokawa Y, Sakashita K, Higuchi T, Takeuchi K, Sawai N, Shiohara M, Kamijo T, Kawa S, Yamashita T, Komiyama A: Retinoic acid is a negative regulator for the differentiation of cord blood-derived human mast cell progenitors. Blood 2000;95:2821-2828.

40 Maret M, Ruffie C, Periquet B, Campo AM, Menevret M, Phelep A, Dziewiszek K, Druilhe A, Pretolani M: Liposomal retinoic acids modulate asthma manifestations in mice. J Nutr 2007;137:2730-2736.

41 Wu J, Zhang Y, Liu Q, Zhong W, Xia Z: Alltrans retinoic acid attenuates airway inflammation by inhibiting Th2 and Th17 response in experimental allergic asthma. BMC Immunol 2013;14:28. 